\title{
ReNPAD: a brazilian network for researchers in High Dilution
}

\author{
Carlos Renato Zacharias, Ricardo Bertagna, \\ Paulo Henrique dos Santos Domingos
}

UNESP - Univ Estadual Paulista, Guaratinguetá, Brazil

\begin{abstract}
Some pertinent questions in the practice of science is to know what one is researching, with whom and where. These questions are even more crucial for those involved in High Dilution studies, an emergent and multidisciplinary scientific field, where concepts, methods and models are still to be validated. In this research field, such questions can be addressed through networks because communication between peers accelerates the process of conceiving and refining the concepts, methodologies and standards that give consistency to emergent knowledge. A thematic network can be effective in building an identity for the science of HDs and related community. This article introduces the project ReNPAD (National Network of Researchers in High Dilutions), a Brazilian initiative aiming to put together researchers involved in studies in HDs in order to stimulate interaction and give visibility to the theirs efforts [1].
\end{abstract}

Keywords: ReNPAD, high dilutions, database, researchers, networks.

[1] Zacharias CR, Bertagna R, Domingos PHS. ReNPAD: a brazilian network for researchers in High Dilution. Int J High Dilution Res [online]. 2009 [cited 2010 Jan 24]; 8(29): 191-198. Available from: http://www.feg.unesp.br/ ojs/index.php/ijhdr/article/view/362/411

\section{(c)) BY-NC-ND Licensed to GIRI}

Support: PROEX, UNESP

Conflict of interest: authors declare there is no conflict of interest

Correspondence author: Carlos Renato Zacharias, zacha@feg.unesp.br.

How to cite this article: Zacharias CR, Bertagna R, Domingos PHS. ReNPAD: a brazilian network for researchers in High Dilution. Int J High Dilution Res [online] 2011 [cited YYYY Month dd]; 10(35): 77-77. Proceedings of the XXIV GIRI Symposium; 2010 Nov 05; Monte Carlo (Monaco). GIRI; 2010. Available from: http://www.feg.unesp.br/ ojs/index.php/ijhdr/article/view/454/469 